\title{
SMART CITY PUEBLA: MEASURING SMARTNESS
}

\author{
iD Stephanie Garcidueñas Nieto ${ }^{1}$ (D) Pablo Collazzo Yelpo ${ }^{2}$ (iD) Katya Pérez Guzmán ${ }^{3}$ \\ ${ }^{1}$ Master's degree in Latin American Studies, University of Vienna - IIASA. Austria. stefgarnie@ gmail.com \\ ${ }^{2}$ Full Professor in Economics, Danube University Krems. Austria pablo.collazzo@donau-uni.ac.at \\ ${ }^{3}$ Research Scholar in Ecosystems Services and Management Program (ESM) - IIASA. Austria. perezguz@iiasa.ac.at
}

\section{Abstract}

Objective of the study: this empirical study revisits the meaning and scope of the 'smart city' concept, measuring 'smartness' in an emerging market setting.

Methodology / approach: a data reduction exercise is conducted through a principal component analysis of 22 smart city variables and a two-step cluster analysis for the 217 municipalities of the State of Puebla (Mexico), so as to identify the defining challenges to 'smartness' in a developing economy city. Originality / Relevance: the prevailing models that measure urban 'smartness', notably Giffinger's and Cities in Motion, arguably miss to capture the socioeconomic challenges of cities in a developing market context.

Main results: two distinctive factors emerge from the data reduction exercise, namely 'marginalization', referring to social and economic inequalities, and 'access to services', particularly public health and education, to define the challenges emerging market cities would need to address in their path to 'smartness'.

Theoretical / methodological contributions: we introduce a revised approach to measure city 'smartness', claiming that access to public services (education and health) helps reduce social inequality and marginalization, which are core indicators to redefine smart cities in emerging markets.

Social / management contributions: even if the analysis is carried out on data from a single region, our findings could be a meaningful input to a more generalizable model to measure city 'smartness' in emerging markets, with implications to multiple stakeholders, particularly policy-makers, suggesting basic inequalities and access to education and health services should be addressed, before attempting to improve traditional smart city indicators.

Keywords: Smart city. Principal components analysis. Inequality; Public services. Emerging markets.

\section{SMART CITY PUEBLA: MEDINDO A 'INTELIGÊNCIA' URBANA}

\section{Resumo}

Objetivo do estudo: este trabalho empírico revisita o significado e o alcance do conceito de 'cidade inteligente', medindo a 'inteligência' urbana em um mercado emergente

Metodologia / abordagem: um exercício de redução de dados é conduzido por meio de uma análise de componente principal (PCA) de 22 variáveis de cidade inteligente e uma análise de cluster em duas etapas, para os 217 municípios do estado de Puebla (México), a fim de identificar os desafios definidores da 'inteligência' em uma cidade em desenvolvimento.

Originalidade / Relevância: os modelos que medem a "inteligência" urbana, especialmente Giffinger e Cities in Motion, não capturam os desafios socioeconômicos das cidades em um contexto de mercado em desenvolvimento.

Principais resultados: dois fatores emergem do exercício de redução de dados, a saber, 'marginalização', referindo-se às desigualdades sociais e econômicas, e 'acesso aos serviços', particularmente saúde pública e educação, para definir os desafios que as cidades de mercados emergentes precisariam enfrentar em seu caminho para a 'inteligência'.

Contribuições teóricas / metodológicas: apresentamos uma abordagem revisada para medir a 'inteligência' da cidade, alegando que o acesso aos serviços públicos (educação e saúde) ajuda a reduzir a desigualdade social e a marginalização, que são indicadores essenciais para redefinir as cidades inteligentes nos mercados emergentes.

Contribuições sociais / de gestão: mesmo que a análise seja realizada em dados de uma única região, nossa pesquisa pode ser uma contribuição significativa para um modelo mais generalizável para medir a 'inteligência' da cidade em mercados emergentes, com implicações para vários stakeholders, em particular para políticas públicas, sugerindo que as desigualdades básicas e o acesso a serviços de educação e saúde devem ser abordados antes de tentar melhorar os indicadores tradicionais de cidades inteligentes.

Palavras-chave: Cidade inteligente. Análise de componentes principais. Desigualdade. Serviços públicos. Mercados emergentes.

\section{SMART CITY PUEBLA: MIDIENDO LA 'INTELIGENCIA' URBANA}

\begin{abstract}
Resumen
Objetivo del estudio: esta investigación empírica revisa el significado y el alcance del concepto de 'ciudad inteligente', midiendo la 'inteligencia' urbana en un contexto de mercado emergente.

Metodología / enfoque: se realiza un ejercicio de reducción de datos mediante la técnica de análisis de componentes principales (PCA) de 22 variables de ciudades inteligentes y un análisis de clúster en dos etapas, para las 217 municipalidades del estado de Puebla (México), de modo de identificar los atributos y desafíos críticos que definen la 'inteligencia' urbana en un mercado en desarrollo.

Originalidad / Relevancia: los modelos que miden la 'inteligencia' urbana, en particular los de mayor difusión, el de Giffinger y Cities in Motion, no reflejan en su totalidad las desigualdades y retos socio-económicos que presentan las ciudades de economías en desarrollo.

Resultados principales: dos factores distintivos emergen del ejercicio de reducción de datos: 'marginación', reflejando marcadas desigualdades económicas y sociales, y 'acceso a servicios', en particular educación y salud públicas. Estos factores representan los desafíos que deberían abordar las urbes de economías emergentes en su conversión a 'ciudad inteligente'. Contribuciones teóricas / metodológicas: desarrollamos un enfoque novedoso para la medición de la 'inteligencia' urbana, argumentando que el acceso a servicios públicos (educación y salud) contribuye a reducir las desigualdades sociales y la marginación, indicadores claves del nivel de 'inteligencia' de una ciudad en un contexto en desarrollo.

Contribuciones sociales / de gestión: si bien el análisis se realiza sobre datos de una región en particular, la evidencia resultante podría ser un insumo relevante para la construcción de un modelo generalizable para la medición de 'inteligencia' de ciudades en mercados emergentes, con implicaciones para múltiples grupos de interés y la política pública, sugiriendo que la resolución de básicas asimetrías socio-económicas y el acceso a educación y salud deberían acometerse antes de aspirar a mejorar los indicadores convencionales de 'inteligencia' urbana.
\end{abstract}

Palabras clave: Ciudad inteligente. Análisis de componentes principales. Desigualdad. Servicios públicos. Mercados emergentes.

\section{Cite as / Como citar}

American Psychological Association (APA)

Garcidueñas Nieto, S., Yelpo, P. C., \& Guzmán, K. P. (2021, Special Issue, March). Smart City Puebla: measuring smartness. Iberoamerican Journal of Strategic Management (IJSM), 20, p. 1-15, e15793. https://doi.org/10.5585/riae.v20i1.15793. 
We argue that there are three main challenges to studying smart cities in Latin America in general and in Mexico in particular: the lack of consensus on the meaning and scope of a smart city; the lack of literature on smart cities within a broader regional context (e.g., the relative abundance of evidence for developed countries vs. developing economies such as Mexico); and the fragmented nature of data at the municipal (city) level in Mexico, the case we consider here.

The lack of a common definition is a recurrent problem. On a practical note, this implies that a smart city can be labeled as such based on very different indicators. Moreover, one should bear in mind that cities are located within broader regional contexts, and different economic and social conditions likely impact the level of smartness attainable by a given city. The well-known variability across Latin American regions, including large social and economic disparities and marginalization, arguably calls for a distinctive definition of smart cities in such a context.

The scarcity of research on the Global South is fairly evident. Searching for "smart cities in Mexico" in Redalyc or SCielo, two of the main open-access search engines for scientific literature in Latin America, produced one result as of December 2018. Such striking evidence arguably showcases the need for more research on smart cities in Latin America.

The state of Puebla in east-central Mexico has been developing an initiative to help its municipalities become smarter. Yet how to track performance (i.e., how to measure smartness) remains a challenge. How can one measure the smartness of a city like Puebla in a way that is both meaningful within the international context of smart cities and relevant to its citizens? What would be the best definition of a smart city for Puebla, given its current socioeconomic challenges?

Here we help fill the gaps in the research on smart cities in developing economies and introduce a working definition of a smart city under the hypothesis that access to public services (e.g., education and health services) helps reduce social inequality and marginalization, which are core indicators to address in a holistic smart city approach. We do this by reporting on a principal components analysis (PCA) of 22 indicators and a two-step cluster analysis of the municipalities of Puebla.

\section{Overview of the relevant literature}

The lack of consensus on the definition of a smart city is a hurdle. Some argue that connectivity, in particular the Internet of Things and an information communication technology infrastructure, is what makes a city smart (Capdevila \& Zarlenga, 2015 Caragliu et al., 2009; Cisco Systems, n.d.; Toppeta, 2010; Washburn et al., 2010). Others argue that building critical infrastructure that allows for the optimization of resources makes a city smart (Hall, 2000; Harrison et al., 2010; Lombardi et al., 2012). Another argument is that a real smart city is a place where innovation and learning are high priorities (Hollands, 2008; Kanter \& Litow, 2009; Komninos, 2008). Finally, others argue that a city is smart when it utilizes technology to improve the quality of life of its citizens in various dimensions, such as the economy, the environment, mobility, people, living, and governance (Giffinger et al., 2007; 
Giovanella, 2013; Lombardi et al., 2011). Given the at times confusing variety of definitions, Garcidueñas (2019) has come up with a working definition that aims to connect the building blocks of a smart city:

\begin{abstract}
A smart city is a competitive city that utilizes its resources in the most efficient, sustainable way and involves all its stakeholders (academia, industry, government and citizens) in the process of decision making to generate economic and social development and foster a superior quality of life for its inhabitants. (p. 18)
\end{abstract}

However, as the proposed definition largely reflects a smart city in a mature economy, one would need to adjust it to capture the Latin American region, including Mexico, the case studied here. Such revised working definition would read as follows:

A smart city in an emerging economy is a city that involves its core stakeholders (industry, academia, government, and citizens) in the process of decision making to develop into a sustainable, efficient location that meets the basic needs of its inhabitants.

The social inequality and disparities in wealth distribution in Latin America are endemic weaknesses that significantly hinder cities (Glaeser et al., 2009) and, consequently, the emergence of smart cities in the region. To build smart cities in developing countries where populations are greater and the demand for services and infrastructure is more pronounced, urban planning should be inclusive, dynamic, resilient, and sustainable (Lazaroiu \& Roscia, 2018). In Mexico, smart cities are still novelties. This may be because most research is focused on the Global North, where resources and policies converge in higher standards of living, which in turn lay the foundation for the development of smart cities. Academics may share part of the blame for the limited attention paid to the Global South in a number of areas, including this one. The single reference cited above from the regional databases we consulted was to the University of Navarra's IESE Cities in Motion index (hereafter, "Cities in Motion"), which generically refers to Mexican cities pursuing a smart city strategy without further discussion of how such smartness is defined, let alone measured (Alvarado, 2018). The index is also somewhat inconsistent, as it changes indicators from year to year, and not all cities that appeared in its initial edition in 2014 remain in the most recent 2018 edition (IESE Business School, 2014, 2015, 2017, 2018).

The state of Puebla, located in central Mexico, is divided into 217 municipalities (Secretaría de Gobernación, 2019). It has developed a smart city initiative aimed at improving universal education, safety, open government, active participation of citizens, and social equity. Given the lack of consistent indicators for measuring and tracking smartness at the city level, we take a closer look at the municipalities of Puebla, under the working hypothesis that access to public services is a core indicator of smartness, which in turn reduces social inequality and marginalization.

A proper baseline provision of basic needs and largely public services, such as schooling and health, is likely to contribute to a build-up of creativity and innovation and as a result reduce inequality and marginalization. The ultimate goal of a smart city is not only to connect inhabitants through 
technology but to fully improve the quality of life and achieve sustainability through reduced emissions, greater use of renewable energy, a redistribution of wealth, and improved innovation, with the key point that diversification in production and the knowledge infrastructure among schools, laboratories, patents, and libraries, among others, leads to innovation (Duranton, 2011; Feldman \& Avnimelech, 2011; Lazaroiu \& Roscia, 2018).

\section{Methodology}

We chose PCA as our methodology because it is able to reduce large quantities of data to a smaller data set while retaining most of the information by finding correlations between indicators and because it uses continuous variables (Karamizadeh et al., 2013). The data were obtained from Consejo Nacional de Población (CONAPO), the National Population Council. This council conducts demographic planning to identify groups in need of development and social programs (Secretaría de Gobernación [SEGOB], 2019), and thus it is in charge of collecting data on marginalization from Mexico.

The data were tabulated across relevant ground indicators of public access to city services (such as education or health) that a city must arguably develop to be smart. These indicators were selected based on those in relevant smart city indices, notably Giffinger et al. (2007; hereafter, "Smart City Index”) and Cities in Motion (IESE Business School, 2018). Both indices identify a large number of variables: 74 for the Smart City Index and 79 for Cities in Motion. Both have several similar indicators but use different data sources and measure them differently. Regardless, both indices are reliable, widely cited data sources. Giffinger et al.'s groundbreaking index has been used as a base model in multiple studies (De Santis et al., 2014; Halleux \& Estache, 2018), and University of Navarra continues to publish Cities in Motion annually, covering more cities and additional indicators each year. It was necessary to study both, as the Smart City Index was the first to measure the smartness of mid-size European cities and provides a reference ground for measuring cities in Latin America with similar standards, and Cities in Motion has included Latin American cities since its inception. However, although both indices include indicators that are relevant to mature economies, the process of developing smartness at the city level in emerging economies requires meeting basic social needs by means of baseline public services that are often taken for granted in advanced economies and hence largely ignored in the literature.

As noted, we selected the data by taking into consideration the categories that appear in Cities in Motion and the Smart City Index in an attempt to measure the ground level of the smartness of the municipalities in Puebla. As the indicators do not necessarily have the same names in both indices - or may not even appear in both indices-Table 1 lists the equivalent indicators for each index.

The selected indicators were total population; medical staff; population entitled to health services; total crime; inhabited dwellings; housing with computer; housing with Internet access; schools; classrooms; libraries; laboratories; workshops; annexes; and state marginalization data for Mexico in 
the year 2015, specifically, illiteracy among people older than 15 years old; the percentage of population older than 15 years old that has not completed an elementary education; the percentage of occupants in housing without drainage; the percentage of occupants in housing without electric power; the percentage of occupants in housing without piped water; the percentage of overcrowded housing; the percentage of occupants in homes with a dirt floor; the percentage of the population that lives in localities with fewer than 5,000 inhabitants; and the percentage of economically active population that earns up to twice the minimum wage (CONAPO, 2010; see Table 2).

The sample included 22 indicators for 217 municipalities, for a total of 4,991 data points. Data were sourced from CONAPO, Instituto Nacional para el Federalismo y el Desarrollo Municipal [National lnstitute for Federalism and Municipal Development], and Instituto Nacional de Estadística y Geografía [National Institute of Statistics and Geography] (INEGI), databases that contain financial, sociodemographic, and economic data on states and municipalities. The data covered the period from 2010 to 2016. As stated above, the data were measured differently, and therefore normalization was necessary. For this process, we performed a standard $\mathrm{Z}$ transformation.

\section{Discussion of findings}

We first extracted a few undetermined factors based only on the criterion of having an eigenvalue greater than 1 . This resolved the question of how many factors to select, as these two factors explained $76.74 \%$ of the variance. Factor 1 explained $58.37 \%$ of the variance alone, and Factor 2 accounted for an additional $18.37 \%$ of the variance. Because "a solution that accounts for 60 percent of the variance is satisfactory" (Hair et al., 2014, p. 107), we performed another PCA choosing to extract only two factors.

The Kaiser-Meyer-Olkin test affirmed that our matrix was useful for analyzing the variables, as a score of 0.914 was obtained. Equally important was that Bartlett's test proved no correlation between the identity matrix and the correlation matrix. With these tests we proved the adequacy of our data sample (see Figure 1).

The component matrix showed that all of our marginalization data were more significant in Factor 2; therefore, we named this factor "Marginalization." In contrast, Factor 1 aggregated most of the data, being almost all highly significant. As these data were quite varied and involved access, population numbers, and services, we named this factor "Access to Services."

In the component plot, all Marginalization (Factor 2) indicators were negatively correlated with Component 1 but positively correlated with Component 2. In contrast, Access to Services (Factor 1) indicators were grouped together positively with Component 1 and Component 2. By this it was possible to infer that when access to services increased, marginalization decreased (see Figure 2).

Following PCA, we performed a two-step cluster analysis using the regression scores obtained from the two PCA factors to identify similarities among the municipalities for each component. We 
chose two-step cluster analysis because it allows the inputting of both continuous and categorical variables. The number of clusters chosen was two, as it passed the test of cluster analysis with a "good" and showed a significant point as seen in Figure 3.

Cluster 1 consisted of 216 municipalities and the national average, all of which were grouped together negatively for Factor 1 and in a mix of positive and negative for Factor 2, depending of the municipality. For example, Municipalities 107 and 72 were topmost in Factor 2 (Marginalization). Municipality 107 is Olintla, which has a very high degree of marginalization and in which almost 56\% of the population has not completed primary school. It also does not have a lot of access to services, especially the Internet and computers, as only 9 and 56 houses have access to the Internet and computers, respectively. Municipality 72 is Huehuetla. This municipality also has a very high degree of marginalization: Illiteracy reaches $35 \%$, and almost $55 \%$ of the population has not finished primary school. Access to services is deficient as well, as it has only 26 medical staff, 59 schools, 1 library, 13 labs, and 5 workshops for 15,689 inhabitants.

On the other end of the spectrum were five municipalities with the least amount of marginalization: Cuautlancingo (Municipality 41), San Andrés Cholula (119), San Martín Texmelucan (132), San Pedro Cholula (140), and Tehuacán (156). It is interesting that four of these municipalities have very low marginalization $(41,119,132,140)$ and one has low marginalization (156). Access to services is also better than in other municipalities. It is important to note that two of the five municipalities (Cuautlancingo and San Andres Cholula) appear to have smart city projects and initiatives in place, according to a smart city Puebla webpage. Cuautlancingo is more dedicated to connectivity and harvesting, and San Andres Cholula is more dedicated to connectivity and security.

Cluster 2 consisted of only two entities. One was the municipality of Puebla, the capital of the state. Puebla is the only municipality in the state with both characteristics deemed necessary to building a smart city: low marginalization and relatively high access to services for its inhabitants. In Figure 4, Puebla (Municipality 114) is closest to the middle of the plot. Puebla also has several smart city initiatives in place, like building bicycle paths and connecting the city via Wi-Fi hotspots. The other entity in this cluster was 218, which was the average data for the state of Puebla. This entity has high access to services for its inhabitants, but its average marginalization is higher than in other municipalities, and therefore it is located in the upper left of Figure 4.

\section{Conclusions and implications}

Smart city initiatives in the state of Puebla are based on 10 dimensions: smart health, smart rural living, smart government, smart environment, smart tourism, smart education, smart mobility, smart economy, smart security, and smart citizens. All of these fall within the six dimensions of Giffinger et al.'s (2007) Smart City Index yet have different measurement metrics. Moreover, it is challenging to compare Puebla to mid-size European cities, not only because of the relative size of the municipalities 
but also because Europe and Latin America are markedly different.

The main concern regarding Cities in Motion (IESE Business School, 2018) is that most of its indicators are outsourced from organizations such as Euromonitor, and there is no clarification of data aggregation (national, regional, or local). Moreover, the cities in the analysis change over the yearsfor instance, there are more Latin American cities in the 2014 index than in the 2017 one. The index therefore may not serve as a reliable measure of Latin American smart cities. It is necessary to use existing data to develop a smart city index that reflects the Latin American reality so decision makers will have more knowledge of what is missing and be able to make more informed decisions.

When we measure only the baseline criteria discussed above for a city to be on the path to smartness, we find that most municipalities in the state of Puebla do not meet these minimum standards. The implications of this finding should not be underestimated, especially as the state is investing in projects and initiatives to become smarter. It is critical to first resolve basic inequalities and secure access to services - mainly education, given the key role it plays in multiple smart indicators.

\section{Limitations and future research}

This was a cross-sectional study on a single region, and thus there are opportunities to replicate our design with multiple regions and cities - in Latin America and beyond-and explore changes in indicators over time.

Regarding the data, INEGI, Mexico's statistics organization, will undertake a big census in 2020. Therefore, it could be relevant to rerun these analyses using the updated data to determine whether municipalities change their position.

\section{References}

Alvarado, R. (2018). Ciudad inteligente y sostenible: Hacia un modelo de innovación inclusiva. Smart and sustentable city: Towards an inclusive innovation model. https://www.redalyc.org/pdf/4990/499054325001.pdf.

Capdevila, I., \& Zarlenga, M. (2015). Smart city or smart citizens? The Barcelona case. https://ssrn.com/abstract=2585682.

Caragliu, A., Del Bo, C., \& Nijkamp, P. (2009). Smart cities in Europe (Serie Research Memoranda No. 0048). https://www.researchgate.net/publication/46433693_Smart_Cities_in_Europe

Cisco Systems. (n.d.). What is a smart city? https://www.cisco.com/c/en/us/solutions/industries/smartconnected-communities/what-is-a-smart-city.html.

Consejo Nacional de Población [National Population Council]. (2010). Índice de marginación por entidad federativa y por municipio [Marginalization index by state and by municipality]. http://www.conapo.gob.mx/es/CONAPO/Indices_de_Marginacion_2010_por_entidad_federativa_y _municipio.

De Santis, R., Fasano, A., Mignolli, N., \& Villa, A. (2014). Smart city: Fact and fiction. http://mpra.ub.uni-muenchen.de/54536/. 
Duranton, G. (2011). Innovation in cities: Classical and random urban growth models. In D. B. Audretsch, O. Falck, S. Heblich, \& A. Lederer (Eds.), Handbook of research on innovation and entrepreneurship (pp. 137-149). Edward Elgar.

Feldman, M., \& Avnimelech, G. (2011). Knowledge spillovers and the geography of innovation revisited: A 20 years' perspective on the field on geography of innovation. In D. B. Audretsch, O. Falck, S. Heblich, \& A. Lederer (Eds.), Handbook of research on innovation and entrepreneurship (pp. 150-160). Edward Elgar.

Garcidueñas, S. (2019). Smart, competitive cities: The case of Puebla [Unpublished master's thesis]. Wien Universität.

Giffinger, R., Fertner, C., Kramar, H., \& Meijers, E. (2007). City-ranking of European medium-sized cities. https://www.researchgate.net/publication/313716484_City-ranking_of_European_mediumsized_cities.

Giovanella, C. (2013). "Territorial smartness" and emergent behaviors. http://www.mifav.uniroma2.it/download/Giovannella_k_teams_v2.pdf.

Glaeser, E., Resserger, M., \& Tobio, K. (2009). Inequality in cities. Journal of Regional Science, 49, 617-646. https://scholar.harvard.edu/files/resseger/files/glaeserressegertobiojrs.pdf.

Hair, J., Black, W., Babin, B., \& Anderson, R. (2014). Multivariate data analysis. Pearson.

Hall, R. (2000, September 28). The vision of a smart city. Presentation at the 2nd International Life Extension Technology Workshop, Paris, France.

Halleux, M., \& Estache, A. (2018). How "smart" are Latin American cities? (Working Paper No. ECARS 2018-05). https://ideas.repec.org/p/eca/wpaper/2013-267226.html.

Harrison, C., Eckman, B., Hamilton, R., Hartswick, J., Kalagnanam, J., Paraszczka, J., \& Williams, P. (2010). Foundations for smarter cities. IBM Journal of Research and Development, 54(4), 1-16.

Hollands, R. (2008). Will the real smart city please stand up? Intelligent, progressive or entrepreneurial? City, 12(3), 303-320.

IESE Business School, University of Navarra. (2014). IESE cities in motion: Methodology and modeling index 2014. https://media.iese.edu/research/pdfs/ST-0335-E.pdf.

IESE Business School, University of Navarra. (2015). IESE cities in motion index. https://media.iese.edu/research/pdfs/ST-0366-E.pdf.

IESE Business School, University of Navarra. (2017). IESE cities in motion index. https://media.iese.edu/research/pdfs/ST-0442-E.pdf.

IESE Business School, University of Navarra. (2018). IESE cities in motion index. https://media.iese.edu/research/pdfs/ST-0471-E.pdf.

Kanter, R. M., \& Litow, S. S. (2009). Informed and interconnected: A manifesto for smarter cities (Working Paper No. 09-141). Harvard Business School. http://www.hbs.edu/faculty/Publication\%20Files/09-141.pdf.

Karamizadeh, S., Abduhlla, S., Manaf, Z., Zamani, M., \& Hooman, A. (2013). An overview of principal component analysis. Journal of Signal and Information Processing, 2013(4), 173-175. 
Komninos, N. (2008). Intelligent cities and globalization of innovation networks. Taylor \& Francis.

Lazaroiu, C., \& Roscia, M. (2018). Smart resilient city and IoT towards sustainability of Africa. 7th International Conference on Renewable Energy Research and Applications (ICRERA), 1292-1298.

Lombardi, P., Giordano, S., Caragliu, A., Del Bo, C., Deakin, M., Nijkamp, P., \& Kourtit, K. (2011). An advanced triple-helix network model for smart cities performance (Research Memorandum No. 2011-45). Vrije Universiteit Amsterdam.

https://www.researchgate.net/publication/241755976_An_Advanced_Triple-

Helix_Network_Model_for_Smart_Cities_Performance.

Lombardi, P., Giordano, S., Farouh, H., \& Yousef, W. (2012). Modelling the smart city performance. Innovation, 25(2), 137-149.

Secretaría de Gobernación [SEGOB]. (2019). Información general [General information]. www.conapo.gob.mx/es/CONAPO/Informacion_General.

Toppeta, D. (2010, October). The smart city vision: How innovation and ICT can build smart, "liveable", sustainable cities (Think! Report No. 005/2010). The Innovation Knowledge Foundation. https://intaaivn.org/images/cc/Urbanism/background\%20documents/Toppeta_Report_005_2010.pdf.

Washburn, D., Sindhu, U., Balaouras, S., Dines, R. A., Hayes, N. M., \& Nelson, L. (2010). Helping CIOs understand "smart city" initiatives: Defining the smart city, its drivers, and the role of the CIO. Forrester Research. 
Table 1 - Classification of indicators used in the study

\begin{tabular}{|c|c|c|}
\hline Indicator & Cities in Motion & Smart City Index \\
\hline $\begin{array}{l}\text { Number of schools and other } \\
\text { education facilities }\end{array}$ & Number of universities & Access to educational system \\
\hline Doctors per municipality & $-^{\mathrm{a}}$ & Doctors per inhabitant \\
\hline $\begin{array}{l}\text { Population entitled to health } \\
\text { services }\end{array}$ & $-^{\mathrm{a}}$ & Hospital beds per inhabitant \\
\hline Total crime & Crime rate & Crime rate \\
\hline $\begin{array}{l}\text { Access to piped water in } \\
\text { housing }\end{array}$ & Access to water & $-^{\mathrm{a}}$ \\
\hline $\begin{array}{l}\text { Percentage of overcrowded } \\
\text { housing }\end{array}$ & $\begin{array}{l}\text { Number of people per } \\
\text { household }\end{array}$ & $-^{\mathrm{a}}$ \\
\hline Housing with Internet access & Number of broadband users & $\begin{array}{l}\text { Broadband internet access in } \\
\text { household }\end{array}$ \\
\hline Total population & Number of inhabitants & $-^{\mathrm{a}}$ \\
\hline Housing with computer & $-^{\mathrm{a}}$ & Computers in household \\
\hline $\begin{array}{l}\text { Percentage of occupants in } \\
\text { housing without drainage, } \\
\text { housing without electric } \\
\text { power, or housing with a dirt } \\
\text { floor }\end{array}$ & $-^{\mathrm{a}}$ & $\begin{array}{l}\text { Share of housing fulfilling } \\
\text { minimal standards }\end{array}$ \\
\hline $\begin{array}{l}\text { Percentage of the } \\
\text { economically active } \\
\text { population that earns up to } \\
\text { twice the minimum wage }\end{array}$ & $-^{\mathrm{a}}$ & Poverty rate \\
\hline
\end{tabular}

Note: ${ }^{\text {aNot available. }}$

Source: Authors' compilation based on data from Instituto Nacional de Geografía y Estadística, Consejo Nacional de Población, Smart City Index, and Cities in Motion.

$\underline{\text { Table } 2 \text { - Comparison of variables at local, regional and national level - Stylistic facts }}$

\begin{tabular}{|c|c|c|c|c|}
\hline Indicator & Puebla & State & Mexico & Units \\
\hline Population (total) 2015 & $1,576,259$ & $6,168,883$ & $119,530,753$ & $\begin{array}{l}\text { Number of } \\
\text { people }\end{array}$ \\
\hline Medical staff (total) & 4,748 & 9,233 & 200,712 & $\begin{array}{l}\text { Number of } \\
\text { medical staff }\end{array}$ \\
\hline $\begin{array}{l}\text { Population entitled to health } \\
\text { services }\end{array}$ & 846,591 & $2,858,894$ & $112,336,538$ & $\begin{array}{l}\text { Total } \\
\text { population } \\
\text { entitled to } \\
\text { health services }\end{array}$ \\
\hline Total crime & 33,433 & 69,346 & $1,696,751$ & $\begin{array}{l}\text { Total registered } \\
\text { crime }\end{array}$ \\
\hline
\end{tabular}




\begin{tabular}{|c|c|c|c|c|}
\hline Indicator & Puebla & State & Mexico & Units \\
\hline Inhabited dwellings & 393,972 & $1,373,171$ & $28,138,556$ & $\begin{array}{l}\text { Total inhabited } \\
\text { dwellings }\end{array}$ \\
\hline Housing with computer & 158,646 & 287,815 & $8,279,619$ & $\begin{array}{l}\text { Total houses } \\
\text { with a computer }\end{array}$ \\
\hline Housing with Internet access & 118,384 & 200,289 & $6,004,315$ & $\begin{array}{l}\text { Total houses } \\
\text { with Internet } \\
\text { access }\end{array}$ \\
\hline Schools & 2,798 & 15,024 & 200,401 & $\begin{array}{l}\text { Total schools } \\
\text { infrastructure }\end{array}$ \\
\hline Classrooms & 20,396 & 71,143 & $1,171,627$ & $\begin{array}{l}\text { Total } \\
\text { classrooms } \\
\text { educational } \\
\text { infrastructure }\end{array}$ \\
\hline Libraries & 122 & 580 & 19,476 & $\begin{array}{l}\text { Total public } \\
\text { libraries }\end{array}$ \\
\hline Laboratories & 1,698 & 3,325 & 49,748 & $\begin{array}{l}\text { Total } \\
\text { laboratories } \\
\text { infrastructure }\end{array}$ \\
\hline Workshops & 647 & 1,405 & 38,932 & $\begin{array}{l}\text { Total } \\
\text { educational } \\
\text { workshops } \\
\text { infrastructure }\end{array}$ \\
\hline Annexes & 17,416 & 70,838 & $1,106,025$ & $\begin{array}{l}\text { Total annexes } \\
\text { educational } \\
\text { infrastructure }\end{array}$ \\
\hline $\begin{array}{l}\text { Illiteracy among people } \\
\text { older than } 15 \text { years old }\end{array}$ & 2.7 & 14.31 & 5.53 & Percentage \\
\hline $\begin{array}{l}\text { Percentage of the population } \\
\text { older than } 15 \text { years old that } \\
\text { has not completed an } \\
\text { elementary education }\end{array}$ & 9.11 & 32.73 & 16.5 & Percentage \\
\hline $\begin{array}{l}\text { Percentage of occupants in } \\
\text { housing without drainage }\end{array}$ & 0.38 & 3.25 & 2.14 & Percentage \\
\hline $\begin{array}{l}\text { Percentage of occupants in } \\
\text { housing without electric } \\
\text { power }\end{array}$ & 0.14 & 1.61 & 0.95 & Percentage \\
\hline
\end{tabular}




\begin{tabular}{lllll}
\multicolumn{1}{c}{ Indicator } & \multicolumn{1}{c}{ Puebla } & State & Mexico & Units \\
\hline $\begin{array}{l}\text { Percentage of occupants in } \\
\text { housing without piped water }\end{array}$ & 3.23 & 9.25 & 5.36 & Percentage \\
$\begin{array}{l}\text { Percentage of overcrowded } \\
\text { housing }\end{array}$ & 22.55 & 42.45 & 28.39 & Percentage \\
$\begin{array}{l}\text { Percentage of occupants in } \\
\text { homes with a dirt floor }\end{array}$ & 0.88 & 8.86 & 3.82 & Percentage \\
$\begin{array}{l}\text { Percentage of the population } \\
\text { that lives in localities with } \\
\text { fewer than 5,000 inhabitants }\end{array}$ & 3.02 & 76.21 & 28.85 & Percentage \\
& & & & \\
& & & & \\
$\begin{array}{l}\text { Percentage of the } \\
\text { economically active } \\
\text { population that earns up to } \\
\text { twice the minimum wage }\end{array}$ & 33.83 & 68.22 & 37.41 & Percentage
\end{tabular}

Source: Authors' compilation based on data from Instituto Nacional de Geografía y Estadística and Consejo Nacional de Población. 
Figure 1 - States Component Matrix

Matriz de componente ${ }^{a}$

\begin{tabular}{|c|c|c|}
\hline & \multicolumn{2}{|c|}{ Componente } \\
\hline & 1 & 2 \\
\hline Puntuación Z(POB_TOT) & .993 & .058 \\
\hline Puntuación Z(ANALF) & -.090 & .874 \\
\hline Puntuación Z(SPRIM) & -.119 & .893 \\
\hline Puntuación Z(OVSDE) & -.041 & .275 \\
\hline Puntuación Z(OVSEE) & -.056 & .622 \\
\hline Puntuación Z(OVSAE) & -.034 & .396 \\
\hline Puntuación Z(VHAC) & -.099 & .514 \\
\hline Puntuación Z(OVPT) & -.075 & .737 \\
\hline Puntuación Z: PL\&lt;5000 & -.114 & .651 \\
\hline Puntuación Z(PO2SM) & -.137 & .774 \\
\hline $\begin{array}{l}\text { Puntuación Z: Medical } \\
\text { staff }\end{array}$ & .991 & .031 \\
\hline $\begin{array}{l}\text { Puntuación Z: Population } \\
\text { entitled to health services }\end{array}$ & .996 & .057 \\
\hline $\begin{array}{l}\text { Puntuación Z: Total } \\
\text { crime }\end{array}$ & .994 & .015 \\
\hline $\begin{array}{l}\text { Puntuación Z: Habited } \\
\text { dwellings }\end{array}$ & .995 & .056 \\
\hline $\begin{array}{l}\text { Puntuación Z: Housing } \\
\text { with computer }\end{array}$ & .989 & .010 \\
\hline $\begin{array}{l}\text { Puntuación Z: Housing } \\
\text { with internet access }\end{array}$ & .984 & .005 \\
\hline Puntuación Z(Schools) & .982 & .088 \\
\hline $\begin{array}{l}\text { Puntuación Z } \\
\text { (Classrooms) }\end{array}$ & .995 & .058 \\
\hline Puntuación Z(Libraries) & .986 & .061 \\
\hline $\begin{array}{l}\text { Puntuación Z } \\
\text { (Laboratories) }\end{array}$ & .992 & .014 \\
\hline $\begin{array}{l}\text { Puntuación Z } \\
\text { (Workshops) }\end{array}$ & .995 & .014 \\
\hline Puntuación Z(Annexes) & .991 & .070 \\
\hline
\end{tabular}

a. 2 componentes extraídos.

Note: ANALF $=$ illiteracy among people older than 15 years old .

SPRIM = percentage of population older than 15 years old that has not completed an elementary education.

OVSDE $=$ percentage of occupants in housing without drainage.

OVSEE = percentage of occupants in housing without electric power.

OVSAE $=$ percentage of occupants in housing without piped water.

VHAC $=$ percentage of overcrowded housing.

OVPT $=$ percentage of occupants in homes with a dirt floor.

PL\&lit;5000 = percentage of the population that lives in localities with fewer than 5,000 inhabitants.

$\mathrm{PO} 2 \mathrm{SM}=$ percentage of economically active population that earns up to twice the minimum wage.

Source: Authors' compilation based on data from Instituto Nacional de Estadística y Geografía and Consejo Nacional de Población. 
Figure 2 - State component plot

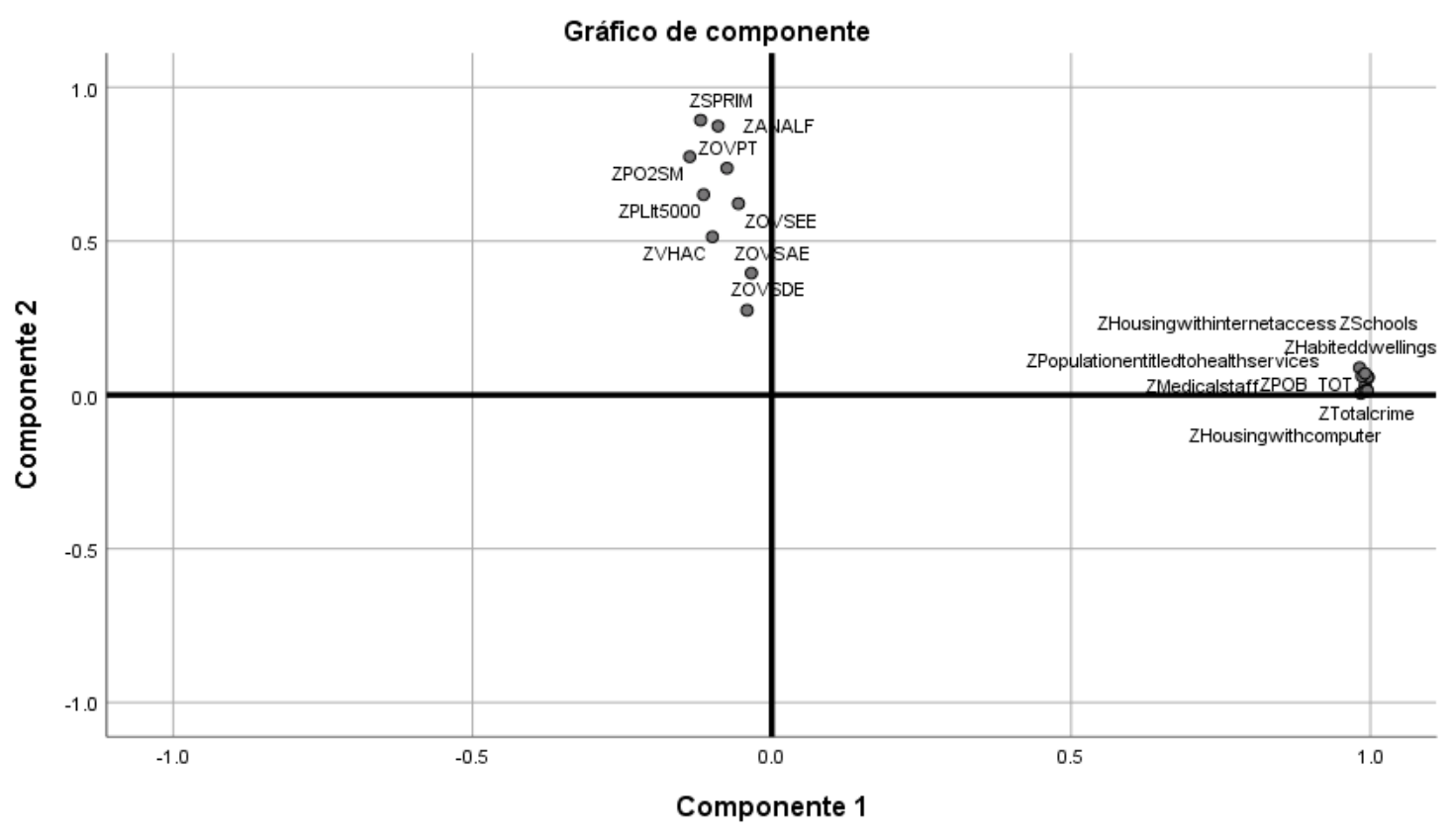

Note: $\mathrm{ZANALF}=\mathrm{Z}$ score for illiteracy among people older than 15 years old.

$\mathrm{ZSPRIM}=\mathrm{Z}$ score for percentage of population older than 15 years old that has not completed an elementary education.

$\mathrm{ZOVSDE}=\mathrm{Z}$ score for percentage of occupants in housing without drainage.

$\mathrm{ZOVSEE}=\mathrm{Z}$ score for percentage of occupants in housing without electric power.

$\mathrm{ZOVSAE}=\mathrm{Z}$ score for percentage of occupants in housing without piped water.

$\mathrm{ZVHAC}=\mathrm{Z}$ score for percentage of overcrowded housing.

$\mathrm{ZOVPT}=\mathrm{Z}$ score for percentage of occupants in homes with a dirt floor.

ZPL\&lit;5000 = Z score for percentage of the population that lives in localities with fewer than 5,000 inhabitants.

$\mathrm{ZPO} 2 \mathrm{SM}=\mathrm{Z}$ score for percentage of economically active population that earns up to twice the minimum wage.

Source: Authors' compilation based on data from Instituto Nacional de Geografía y Estadística and Consejo Nacional de Población.

Figure 3 - Puebla's Cluster Quality Value

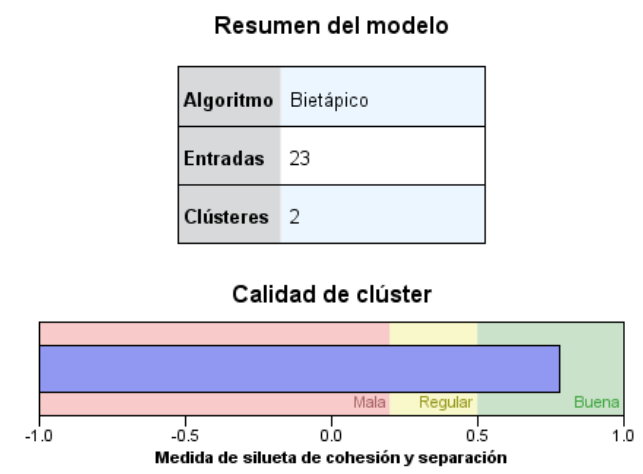

Source: Authors' compilation based on data from Instituto Nacional de Estadística y Geografía and Consejo Nacional de Población. 
Figure 4 - Puebla's Cluster Analysis

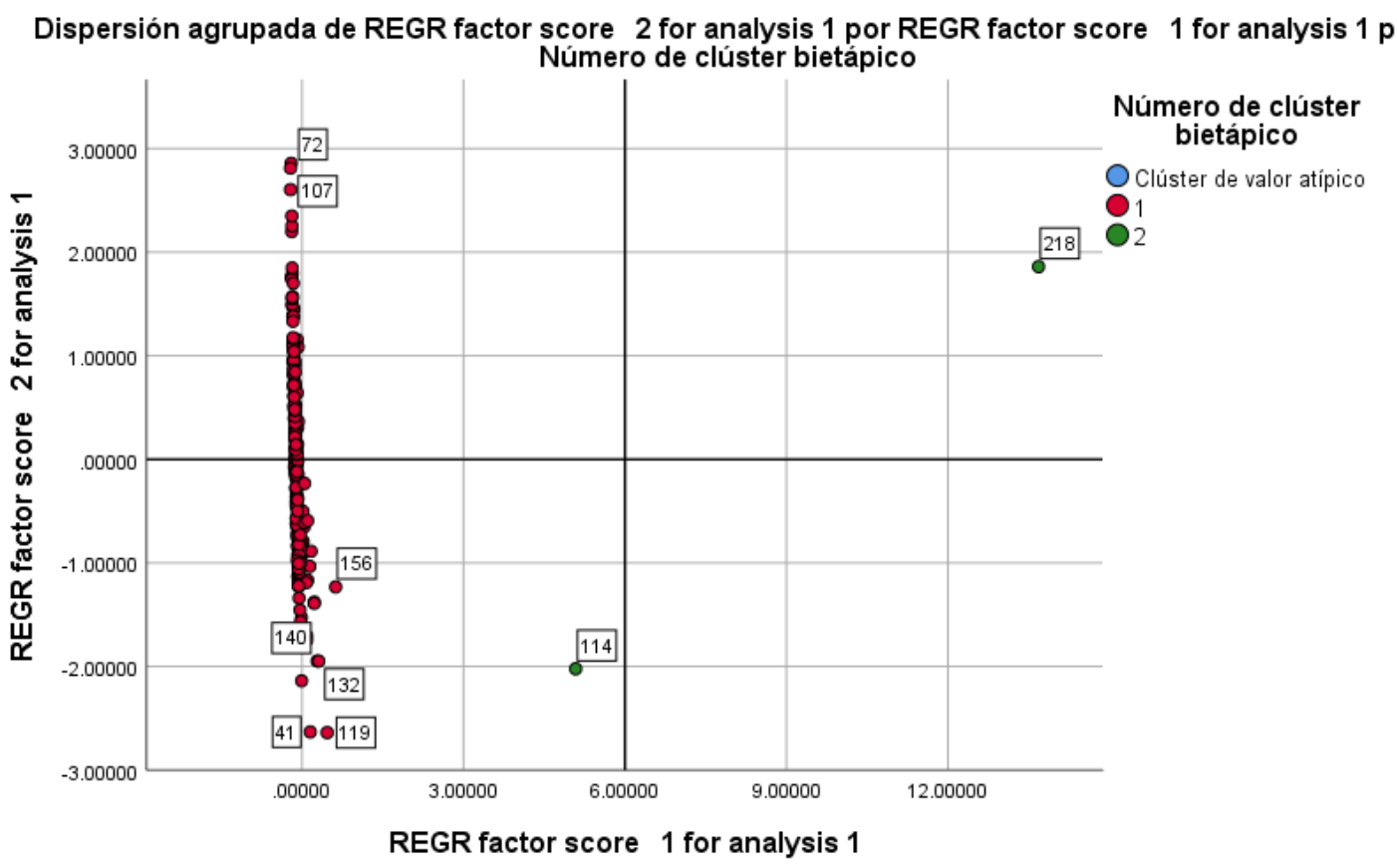

Note: REGR $=$ Regression.

Source: Authors' compilation based on data from Instituto Nacional de Estadística y Geografía and Consejo Nacional de Población. 